\title{
THE USE OF ATYPICAL FORMS OF EMPLOYMENT WITH THE AIM OF PROFESSIONAL ACTIVATION OF THE UNEMPLOYED
}

\begin{abstract}
One hallmark of Polish unemployment regulations introduced gradually from the early 1990s is that apart from protective actions i.e. unemployment benefits they make provision for instruments supporting professional activation of the unemployed. Throughout time the regulations concerning this matter evolved and new forms of support for the unemployed were introduced, taking into account the needs of the changing labour market. The necessity of tackling the challenges of the labour market in post-industrial economy, especially in terms of increasing employment flexibility, led to development and rise in significance of atypical employment forms. Such solutions are also used in encouraging professional activation of the unemployed. This study comprises analysis of three atypical employment practises: part-time employment, telework and temporary employment which apply to the unemployed in accordance with the rules of the Act of 20 April 2004 on employment promotion and on labour market institutions, regulations about job market instruments.
\end{abstract}

Słowa kluczowe: aktywizacja zawodowa bezrobotnych, zatrudnienie nietypowe, praca w niepełnym wymiarze czasu pracy, telepraca, zatrudnienie tymczasowe

Keywords: encouraging professional activation of the unemployed, atypical employment, part-time employment, telework, temporary employment

ASJC: 3308 , JEL: K31

\section{Introduction}

In the post-industrial economy the processes such as globalisation, technological progress, especially in the areas of information and communication technology, but also unemployment arising during the cyclical crises could not avoid having an impact on the job market. The necessity of tackling new challenges of the job market, particularly those concerning the increase in employment flexibility, led to development and rise in significance of atypical employment forms. For satisfying the needs of the employers 
in the economy built on knowledge and information, in which most new jobs are in the services sector, traditional model of employment proved to be insufficient.

While the way of defining typical, and even more so atypical employment can be subject to controversy, it is widely accepted that typical employment means working only based on the permanent employment contract, full-time, for the employer (who is Party to the contract) and in a specified location, most of the time in the place of work of the employer. The employment contract which does not have all of the aforementioned qualities should be therefore considered atypical form of employment (Florczak 2017, p. 18).

Apart from the atypical employment contract, another type of such a contract can be distinguished-atypical non-employment contract, which is based on the civil-law regulations of work provision.

Both types of the atypical forms of employment undoubtedly provide the flexibility of employment, much needed by the employers, but also have negative consequences, mainly in segmentation of the job market, as well as in worsening the social security among the employees, and as a result they lead to precarisation of labour (Florczak, Otto 2019, p. 22).

On the other hand, utilising non-typical forms of employment creates employment opportunities for people who would otherwise be excluded from the job market, and that's the reason for the increase in employment flexibility becoming a way of creating new jobs and fighting unemployment in the European Union countries in the 1990s (Szylko-Skoczny 2004, p. 252).

Whether the atypical forms of employment can actually lead to the professional activation of the unemployed is the subject of this study. It contains the analysis of parttime employment, telework and temporary employment based on the Act of 20 April 2004 on employment promotion and on labour market institutions (Dz.U. 2020, item 1409 consolidated text, hereinafter referred to as: the Act on employment promotion).

\section{Rights in part-time employment}

The part-time employment is considered the best known and popular type of atypical employment according to scientists from various disciplines. Since it serves the purpose of making working time more flexible, it is classified as a flexible form of employment and working time organisation (Jaroszewska-Ignatowska 2018, p. 46).

Part-time employment has various effects, both economic, mostly in the services sector, as well as social, not only constituting a way of reducing unemployment but also providing employment opportunities for people who cannot take up full-time work due to their psychophysical state or their commitments outside of work.

Despite many advantages of such a form of employment, it is not very popular and widely spread as compared to UE15 countries (Jaroszewska-Ignatowska 2018, pp. 7683). The reasons for this are complex, and comprise treating part-time employment as 
low quality, low-paid and with limited capacity for promotion (Skórska 2008, p. 187). It is also due to the fact that creating an institution which would promote part-time employment while respecting employees' interests has not been attempted in Poland (Wratny 2015, p. 297). For achieving this goal sole implementation of Council Directive 97/81/EC concerning the Framework Agreement on part-time employment cannot be considered sufficient.

Based on the Act on employment promotion, Art. 48(1)(1) should be considered as a regulation which stimulates taking up part-time employment. The provision stipulates the right for incentive pay for the unemployed who also have the right for unemployment benefits and who, after being referred by the regional Labour Office, undertook a part-time job as understood by the working time regulations and earn less than minimum wage.

The amount of incentive pay is equal to the difference between the actual earnings and the minimum wage; however, is not to be higher than $50 \%$ of the unemployment benefits (base unemployment benefits, as stated in Art. 72(1) of the Act on employment promotion) at the time of receiving the benefits. The incentive pay is therefore designed to compensate, at least in part, not receiving higher pay for work, which they would be getting if they were working full-time.

The right to the incentive pay mentioned in Art. 48(1)(1) of the Act on employment promotion, is realised only when employed, that is through an employment agreement, service relationship or outwork (Art. 2(1)(43) of the Act on employment promotion).

Despite undertaking employment that complies with the aforementioned regulations, the incentive pay will not be received by the employee if they have been assigned to intervention works (work incentivised by the government on the employer side), public works or to a workplace in which equipment was funded by the Labour Fund.

Apart from the aforementioned regulation, no other rule in the Act on employment promotion can be classified as stimulating part-time employment. On the contrary, there are a few regulations in the Act which can be considered discouraging with relation to the discussed form of atypical employment. An example of this can be the definition of unemployment as a situation when an individual is willing and able to work full-time or undertake other forms of gainful full-time employment (with the exception of the disabled for whom the full-time requirement is halved) and the fact that the unemployment status is incompatible with undertaking part-time jobs, even when it is the employer who is at fault of reducing working time. The latter example proves that the Polish legislator does not accept the concept of so called partial unemployment which-in accordance with international, EU and national law of many of the foreign legislations-does qualify for protection and ensures entitlements laid down by the law. 


\section{Telework}

Another atypical employment practice is telework, though according to some authors, its classification originated from the way in which the legislator regulated telework at the beginning (Gersdorf 2014, p. 551). The non-typical element, considering qualities of standard form of employment, is the workplace. One of the most important properties of remote work is working outside the employing establishment. It means that work is to be done outside of the registered office or any other branch that comprise workplace (Rączka 2014, p. 818). Therefore the workplace can be located at home of the person working remotely, as well as in any other place which provides internet connectivity (mobile telework-nomadic).

From an employee's standpoint, an essential advantage of such a form of employment is the ability to work from home. It is especially important for people who cannot work in the office due to their disability or the need to take care of children or adult family members. In 2014 the aforementioned circumstances probably inspired introduction of a new measure to the Act on employment promotion, i.e. telework grant (Dz.U. 2014, item 598). That grant, in accordance with Art. 60(1) of the Act on employment promotion, is approved by the County Governor based on the agreement to create a remote work position financed by the Labour Fund.

This regulation determines a set of entities for whom this grant can be approved, as well as the beneficiaries of this instrument, i.e. the unemployed for whom new remote work positions can be created. The application for the grant can be submitted by employers, i.e. corporate entities, even those who do not have a legal personality and natural persons who employ at least one worker, and entrepreneurs, so natural persons, legal persons or corporate entities which are not legal persons but which a separate act grants legal capacity (Art. 4(1) of the Act of 6 March 2018-Entrepreneurs' Law, Dz.U. 2019, item 1292) and which perform business activity.

The legislator distinguishes between two categories of the unemployed who can do remote work, i.e. 1) the unemployed who is coming back to the labour market and who has at least one child below the age of $6 ; 2$ ) the unemployed who provides care to a dependent person, that is a person who requires continuous observant care due to the state of health or age, and who is either a family member or has affinity with the person receiving the services or instruments of labour market, or living in a common household.

Another requirement for the unemployed to get this grant is to resign from work or other gainful employment due to the necessity of child-rearing or providing care to the dependants in a 3-year period before registering as an unemployed.

This premise means that the extent of this benefit cannot encompass people who, before providing care to children or dependants, were not economically active (in the forms specified in the Act on employment promotion). The validity of this statement is confirmed in the Art. 60(1) with the remark about the return to the labour marketit is obvious to demonstrate that returning to the labour market is only possible if an individual was present in it before. 
Such a presentation of personal scope does significantly narrow down the set of individuals who would be able to benefit from such entitlement as it excludes the unemployed who previously were not economically active, due to e.g. providing childcare (Latos-Miłkowska 2018, p. 703).

Another type of a restriction is presented in the Art. 60 of the Act on employment promotion as it excludes the unemployed for whom a remote work position cannot be created due to the relationship with the employer or entrepreneur (being a member of their family). This regulation should be considered justifiable as it counteracts fraudulent practises which would obtain funds from Labour fund by deception through creating fictious positions for relatives of the employer or entrepreneur (Florczak 2018, p. 1038).

The grant rate specified by the Act as not higher than six times the minimum wage level at the time of concluding the agreement for every unemployed committed (it means that the hiring employer can receive a grant in order to create more than one telework position), can be considered the amount which enables the employer (entrepreneur) complete avoidance, or a major reduction in the start-up costs of remote work position arrangement. It can constitute an incentive to utilise this labour market instrument by the entitled entities.

In my view, similar characteristics can be attributed to the regulation according to which the employer (entrepreneur) is not obliged to conclude an indefinite-term contract with the committed unemployed. Article 60a(4) of the Act on employment promotion requires the employer to hire the unemployed for no less than 12 months in case of full-time employment or 18 months in case of half-time employment. This regulation does not include any incentives stimulating the employer (entrepreneur) to prolong the employment above the required minimum duration, hence it can be anticipated that the material labour market instrument will serve as a transition mechanism for economic mobilisation of the unemployed in the majority of cases. However, the deciding factor in the mobilisation of the unemployed is not the interest of employers or the availability of County Governor funds, but it is the job qualifications of the unemployed. In the subject literature there is a wide agreement that telework requires a high level of skills and specialist knowledge, which indirectly stems from the fact that not every type of work can be done in that form of employment (Latos-Miłkowska 2003, p. 73; Lewandowicz-Machnikowska 2018, p. 336). Nevertheless, the majority of the unemployed do not have any qualifications, or show a low level thereof, which are insufficient for doing work suitable for a remote position. It can be a reason for dismissing this labour market instrument and questioning its validity.

In my estimation, in order to increase the importance of the telework grant, the personal scope of grant beneficiaries should be extended to encompass the unemployed who are also disabled. From the beginning of its development, telework was considered an important tool for encouraging vocational activation of the disabled. The subject literature often points out that using modern technology for service provision-typical for telework-decreases the importance of the psychophysical condition of the employees and makes labour market opportunities more equal for the disabled (Madej 2014, 
p. 135). In light of Art. 60(1) of the Act on employment promotion there are no legal obstacles to employ disabled unemployed workers using the aforementioned labour market instrument. According to this Article, service can be provided by the committed unemployed worker on a half-time basis. Noting that a prerequisite for getting the unemployment status is, in the case of the disabled, the ability and willingness to undertake work in a given profession or service in at least a half-time form, the regulation in Art. 60(1) can be regarded as encompassing disabled unemployed people. Such an interpretation would be very desirable in light of a low level of professional activity of the disabled in Poland (Szabłowska-Juckiewicz 2017, p. 720).

\section{Temporary employment}

The Act on employment promotion tells us that employment agencies can support Employment Offices in encouraging professional activation among the unemployed. The regulatory solutions in this domain result from so called contract award procedures which means delegating some of the public employment institutions' tasks to private institutions through an agreement. The need for such cooperation of public institutions and the private sector has been pointed out for a long time. It is advised, among others, by the Convention No. 181 of the International Labour Organisation about Private Employment Agencies (Reda-Ciszewska 2018, p. 586).

The earliest examples of contract award procedures applied in the Polish legal system concern commissioning private sector agents to organise training programs, and later it was extended to job placement services (Kukulak-Dolata 2016, p. 197; nevertheless, the author notes that in the area of job placement this option was not used). In two amendments to the Act on employment promotion of 2008 (Dz.U. 2009, No. 6, item 33) and 2014 (Dz.U. 2014, item 598) new regulations were introduced. They constitute the basis for public employment institutions and private sector employment agencies to cooperate with regards to encouraging vocational activation among certain categories of the unemployed.

Considering the subject of this study, the regulation in Art. 61b of the Act on employment promotion should be analysed. This regulation provides for committing the unemployed in special circumstances of labour market ${ }^{1}$ to undertake work or other forms of gainful employment based on a civil-law agreement, constituting appropriate work, with the duration no shorter than six months.

In the subject literature it is agreed that the definition of committing the unemployed to employment is the undertaking work (gainful employment) for a third party

${ }^{1}$ According to the Art. 49 of the Act on employment promotion, this category comprises the unemployed under 30 , long-term unemployed, unemployed over 50 , unemployed who are also social services recipients, unemployed who have at least one child below 6 years old, unemployed who have at least one disabled child under 18 and the disabled unemployed. 
as a consequence of employment agency service, as well as concluding employment agreement or civil-law agreement with the employment agency for temporary work (Bielak-Jomaa 2016, p. 640). In the latter case, the unemployed will be granted the status of temporary worker or a person who is not the employee of the agency but is delegated to temporary work on the basis of civil-law agreement. It means that in case of performance of a contract (in accordance with Art. 61b of the Act on employment promotion) by the employment agency, the unemployed will be providing services in accordance with the atypical form of employment-temporary employment-regulated in the Act on hiring temporary employees of 9 July 2003 (Dz.U. 2019, item 1563 consolidated text). The atypical nature of the employment in this case stems from a specific personal configuration. In this case three entities are involved in a legal relationship: temporary employee, temporary employment agency - as an employer, and hiring employer.

A more detailed analysis concerning objective forms of employment does not seem necessary in this study, moreover, the scope of the study restricts us from doing so. Hence, the main focus will be placed on one aspect regarding the aim of the regulation encompassed in the Art. $61 \mathrm{~b}$ of the Act on employment promotion. This aspect concerns undoubtedly encouraging professional activation of the unemployed, even shortterm, since according to the aforementioned regulation gainful employment should last at least six months. ${ }^{2}$ Such a period specified in the regulation is not surprising given that temporary character of employment is, in a sense, the core of temporary employment agency activity (Mitrus 2015, p. 397). For the Parties concerned by the regulation (the unemployed in special labour market circumstances, especially those in long term unemployment, unemployed below 30 or above 50 ) even short-term vocational activation certainly has its importance. On the other hand, the most desirable outcome anticipated by the government is to provide more stable employment opportunities for the unemployed. It seems that when it comes to the objective labour market instrument, the above-mentioned effect can only be achieved when the hiring employer employs their worker after the temporary work period. Article 12 of the Act on hiring temporary employees can be seen as some form of bond of such a solution as it foresees the possibility of voiding the agreement between the temporary employment agency and the hiring employer about the condition of not employing the temporary worker after finishing the temporary employment period. This rule, in accordance with Art. 25a(1) of the Act on hiring temporary employees, is extended to those employed through civillaw agreements, that is those who provide services by means of "other gainful employment." It means that both the unemployed who were employed through employment contract and those employed through civil-law agreements can potentially continue their employment, on the arrangement and conditions agreed with the hiring employer, for whom temporary work has been done.

${ }^{2}$ In the original version of Art. $61 \mathrm{~b}$ of the Employment Promotion Act the minimum employment period was set to 1 year. Moreover, it only concerned committing the unemployed to undertake work, contrary to the current version of the Article, which also involves other forms of gainful employment. 
Perhaps these considerations are too optimistic, but, in my view, we cannot dismiss the possibility of such a beneficial (from the unemployed standpoint) sequence of employment forms resulting from utilising the discussed labour market instrument occurring in practice. Atypical forms of employment should be of transitional nature, enabling gaining permanent employment, and not replacing it (Pisarczyk, Torbus 2019, p. 206).

\section{Conclusion}

In summary, it should be noted that introducing regulations about atypical forms of employment to unemployment laws is a proof of continuous search for new instruments that encourage professional activation among the unemployed by the legislator. A particular advantage of the discussed solutions-part-time employment, telework and temporary employment-is gaining employment status (such a status will not be gained by the unemployed who is employed through a civil-law agreement; however, this agreement should satisfy the conditions of proper employment, including guarantees of social security) by the unemployed. This, in turn, means that they are working under the Labour Code (Dz.U. 2019, item 1040 consolidated text, as amended) regulations, as well as-in the case of temporary employees - under the Act on hiring temporary employees. Those regulations guarantee, at least formally, equal treatment of the employees employed through the discussed forms with those employed in a traditional way (nonetheless, some differences and separation, which stem from the character or working conditions of atypical employment forms, still may occur). It is also worth noting that two of the discussed forms of employment-telework and temporary employment-apply only to specific types of unemployment. It is, in my view, an informed decision due to the legitimate assumption about the need to differentiate unemployed status and assure some subsets thereof more direct and strong state intervention in order to increase their chances for employment (Szylko-Skoczny 2004, p. 225).

The above conclusions justify generally a positive evaluation of the regulations concerning the discussed forms of employment. However, one important flaw of those regulations, in light of their aim-encouraging professional activation of the unemployed-is that the resulting employment will usually turn out temporary. Despite it having some advantages (Kosut 2009, p. 323), it does not change the situation of the unemployed in a significant way.

On the other hand, because of the modern labour market requirements, the unemployed have to be ready to undertake employment in its atypical forms (Kosut 2009, p. 323), which often involves short-term work periods. Therefore, assuming that the occurrence of atypical employment forms is inevitable, the principal concern is to prevent the misuse of them. This problem was addressed by the EU administration through The European Pillar of Social Rights signed on 17 November 2017 by the European Council, European Parliament and European Commission. Among its twenty principles, the 
principle regarding safe and flexible employment included the prohibition of abusing atypical employment agreements as those leading to uncertain working conditions.

\section{References}

Bielak-Jomaa E. (2016) [in:] Z. Góral (red.), Ustawa o promocji zatrudnienia i instytucjach rynku pracy. Komentarz, Warszawa.

Florczak I. (2017) Status prawny osób świadczacych pracę w ramach umownego zatrudnienia nietypowego, Łódź.

Florczak I. (2018) K. W. Baran, M. Włodarczyk (red.), System prawa pracy, t. 8: Prawo rynku pracy, Warszawa.

Florczak I., Otto M. (2019) Praca prekaryjna a unijne instrumenty regulacyjne: obecne realia i perspektywy zmian [in:] I. Florczak, M. Otto (red.), Prekaryzacja zatrudnienia. Wyzwania dla prawa pracy $w$ Europie, Warszawa.

Gersdorf M. (2014) [in:] M. Gersdorf, K. Rączka, M. Raczkowski, Kodeks pracy. Komentarz, Warszawa.

Jaroszewska-Ignatowska I. (2018) Zatrudnienie w niepełnym wymiarze czasu pracy, Warszawa.

Kosut A. (2009) Bezpieczeństwo socjalne bezrobotnych powyżej 50 roku życia [in:] A. M. Świątkowski (red.), Ochrona praw człowieka $w$ świetle przepisów prawa pracy i zabezpieczeń społecznych, Warszawa.

Kukulak-Dolata I. (2016) Rola kontraktacji w aktywizacji lokalnego rynku pracy, "Acta Universitatis Lodziensis Folia Oeconomica," Vol. 4, t. 3240.

Latos-Miłkowska M. (2003) Telepraca jako sposób upowszechniania zatrudnienia [in:] L. Florek (red.), Prawo pracy a bezrobocie, Warszawa.

Latos-Miłkowska M. (2018) [in:] K. W. Baran, M. Włodarczyk (red.), System prawa pracy, t. 8: Prawo rynku pracy, Warszawa.

Lewandowicz-Machnikowska M. (2018) Wsparcie zatrudnienia opiekunów osób zależnych $z$ powodu wieku w ustawie o promocji zatrudnienia i instytucjach rynku pracy [in:] T. Kuczyński, A. Jabłoński (red.), Prawo pracy i prawo zabezpieczenia społecznego. Teraźniejszość i przyszłość. Księga Jubileuszowa Profesora Zdzisława Kubota, Warszawa.

Madej M. (2014) Wykorzystanie pracy w formie telepracy przez osoby niepetnosprawne [in:] A. Giedrewicz-Niwińska, M. Szablowska-Juckiewicz, (red.), Zatrudnianie osób niepełnosprawnych. Regulacje prawne, Warszawa.

Mitrus L. (2015) Praca zarobkowa a bezpieczeństwo socjalne (uwagi na tle przekształceń rynku pracy) [in:] A. Kosut, W. Perdeus (red.), Przemiany prawa pracy. Od kodyfikacji do współczesności. Księga jubileuszowa dedykowana profesor Teresie Liszcz, "Studia Iuridica Lublinensia," Vol. 24.

Pisarczyk Ł., Torbus U. (2019) Praca prekaryjna w Polsce. Zwalczanie nadużywania nietypowych form zatrudnienia [in:] I. Florczak, M. Otto (red.), Prekaryzacja zatrudnienia. Wyzwania dla prawa pracy w Europie, Warszawa. 
Rączka K. (2014) [in:] M. Gersdorf, K. Rączka, M. Raczkowski, Kodeks pracy. Komentarz, Warszawa.

Reda-Ciszewska A. (2018) [in:] K. W. Baran, M. Włodarczyk (red.), System prawa pracy, t. 8: Prawo rynku pracy, Warszawa.

Skórska A. (2008) Praca w niepełnym wymiarze czasu pracy szansą na zwiększenie aktywności zawodowej kobiet. Doświadczenia krajów UE [in:] C. Sadowska-Snarska (red.), Elastyczne formy pracy. Szanse i zagrożenia, Białystok.

Szabłowska-Juckiewicz M. (2017) Aktywizacja zawodowa jako metoda przeciwdziałania wykluczeniu społecznemu osób niepełnosprawnych [in:] Tendencje rozwojowe indywidualnego i zbiorowego prawa pracy. Księga jubileuszowa Profesora Grzegorza Goździewicza, Torun.

Szylko-Skoczny M. (2004) Polityka społeczna wobec bezrobocia w Trzeciej Rzeczypospolitej, Warszawa.

Wratny J. (2015) Z problematyki prawnej zatrudnienia w niepelnym wymiarze czasu pracy [in:] A. Kosut, W. Perdeus (red.), Przemiany prawa pracy. Od kodyfikacji do współczesności. Księga jubileuszowa dedykowana profesor Teresie Liszcz, "Studia Iuridica Lublinensia," Vol. 24.

\section{Legal acts}

The Labour Code Act of 26 June 1974, Dz.U. 2019, item 1040 consolidated text, as amended. The Act of 9 July 2003 on hiring temporary employees, Dz.U. 2019, item 1563 consolidated text. The Act of 20 April 2004 on employment promotion and on labour market institutions, Dz.U. 2020, item 1409 consolidated text.

The Act of 19 December 2008 amending the Act on employment promotion and labour market institutions and some other acts, Dz.U. 2009, No. 6, item 33.

The Act of 14 March 2014 amending the Act on employment promotion and labour market institutions and some other acts, Dz.U. 2014, item 598.

The Act of 6 March 2018-Entrepreneurs' Law, Dz.U. 2019, item 1292 consolidated text, as amended. 